\title{
109. A Study of the Recent Deep-Water Coral Fauna of Japan.
}

\author{
By Hisakatsu YABE and Motoki EguCHI. \\ (Comm. by H. YABE, M.I.A., Oct. 12, 1932.)
}

In this article we are concerned with the deep water coral fauna of the Japanese seas; the materials of the deep water corals we examined are procured by the surveying ship Sôyo-maru of the Imperial Fisheries Institute, Tokyo. During her cruises, October 1922 to September 1930, in the shelf sea bordering Honshû, Shikoku and Kiushû, dredge operation and other oceanographical observations were prosecuted by her officers at 658 stations; the bottom samples obtained from her 175 stations are found to contain deep water corals.

Among some 400 specimens of deep water corals in the Collection there are discriminated 89 species and subspecies in 30 genera and subgenera distributed in 6 families. The genera and subgenera are enumerated below, with the number of species and subspecies.

Turbinolidae: Caryophyllia (13), Ceratotrochus (1), Conotrochus (3), Goniocyathus, n. g. (1), Fragilocyathus, n. g. (1), Trochocyathus (2), Tropidocgathus (2), Paracyathus (1), Odontocyathus (3), Deltocyathus (5), Citharocyathus (1), Deltocyathoides, n. g. (1), Discotrochus (3), Cyathoceras (2), Desmophyllum (3), Heterocyathus (3). Flabellidae: Flabellum (14), Blastotrochus (1). Astraeidae: Goniocorella, n. g. (2), Parasmilia (1), Cladocora (1). Oculinidae: Cyathohelia (1), Sclerohelia (1). Fungidae: Fungia (Diaseris-form) (1), Bathyactis (2). Eupsammidae: Balanophyllia (8), Dendrophyllia (8), Endopachys (1), Heteropsammia (1), Stephanophyllia (2).

The most common species is Flabellum distinctum M. E. \& H., with more than 50 specimens from 38 stations; followed by $F$. transversale Mos., Balanophyllia fistula Alc. and Deltocyathus orientalis Dunc., while all the remaining species, with a few exceptions, are represented by more than 10, usually 20-30 specimens. The first and last species as well as $F$. deludens Marenz. are cosmopolitan.

Of 30 genera and subgenera enumerated above, only 4 are new; the other genera, 26 in number, cover nearly all of the genera of deep water corals from the western Pacific. Of 89 species and subspecies, some 30 are new and 43 are definitely identified with the forms previously described from the Hawaiian, Philippine and southern seas, while the remaining forms are those either more or less closely allied to or those in need of closer comparison with the original materials of the known species. 23 of definitely identified species are in common with the 
Philippines and 8 with the Hawaiian seas, while the others are known from the Malayan archipelago.

Stephanotrochus spinifer, Eupsammia stimpsoni and Javania insignis once described from Japan by Marenzeller, Verrill and Duncan repectively, are not represented in this collection; also Anisopsammia living in the Sagami-nada is not found in the bottom samples. More comprehensive dredge operations in the future will certainly raise the number of genera and species in our deep water coral fauna.

The shelf sea bordering the Japanese Islands is divisible into 3 regions according to the distribution of deep water corals: (1) the shelf sea along the Japan Sea coast of Honshû extending to the Tsushima Strait, (2) that along the Pacific coast of Honshû approximately north of the lat. $36^{\circ} \mathrm{N}$. and (3) that along the Pacific coast of central Honshû, south of the lat. $36^{\circ}$ N., Shikoku and Kiushû, thence extending to the Genkai-nada. The northern boundary of the last region almost coincides with the northernmost limit of the distribution of reef-corals in the Japanese seas.

Nearly all of the species discriminated are found in the third region, while very few of them are obtained from the first and second regions; from the first region we have only Dendrophyllia japonica Rehb., D. arbuscula V.-d.-Horst, Sclerohelia n. sp., Flabellum transversale, Fragilocyathus conotrochoides n. sp., Caryophyllia ephyala Alc., Deltocyathus orientalis and a few other indeterminable forms, and from the second only Heterocyathus n. sp., $F$. transversale, $F$. distinctum, $D$. orientalis and Balanophylia fistula. Of these 9 species, 3 belong to the cosmopolitan forms mentioned above, and the others are also common in the third region, except Heterocyathus n. sp. not yet known from the third region and Fr. conotrochoides rather common in the first region, but apparently very rare in the third.

Deep water corals are living fairly common in the first and second regions, but their fauna is a very impoverished one on that of the third region as to the number of genera and species. The change from one to the other is abrupt.

As once stated by Yabe and Sugiyama, reef-corals are living along the Pacific coast of Honshû, Shikoku and Kiushû in the depths 5-40 m. ; on the other hand, deep water corals seem to be most common in the depths $100-250 \mathrm{~m}$. The bathymetrical range of the species are:-

$46 \mathrm{~m} .1 \mathrm{sp}$. (Heteropsammia n. sp.); $55 \mathrm{m.} 1 \mathrm{sp}$. (Heterocyathus (Stephanoseris) n. sp.) ; 70-100 m. 11 sp. ; 100-150 m. 36 sp.; 150-200 m. 33 sp., 200-250 m. 30 sp.; 250-300 m. 10 sp. ; 300-350 m. 19 sp.; 350-400 m. 11 sp. ; 400-500 m. 5 sp. ; 500-600 m. 8 sp., 600 m. 2 sp. (Conotrochus sp., Deltoyathus vaughani, n. nom.); $604 \mathrm{~m} .3$ sp. (Caryophyllia ephyala, and var., C. laevicostata Moseley); 658 m. 3. sp. (Flabellum distinctum, F. sp., Endopachys japonicum Yabe \& Eguchi). 
Some of the species have a wide bathymetrical range: Endopachys japonicum 70-650 m., Flabellum distinctum 70-658 m., Caryophyllia ephyala 70-604 m., Deltocyathus vaughani n. nom. (=Levipalifer orientalis Vaughan) 100-600 m., and Conotrochus sp. 150-600 m.

In the following lines the four new genera are defined:

Fragilocyathus, n. g. Genotype: F. conotrochoides n. sp. (Fig. 1). Turbinoliid. Corallum simple, cylindro-conical, attached laterally near its pointed base upon septa of an older one (septal budding); fragile, showing a tendency to easily split longitudinally. Epitheca relatively thick. Calice circular, very deep. Septa fairly stout, not exsert, upper margin entire, inner margin free and dentated by irregularly spaced nodulous processes; arranged in hexameral plan and in 4 cycles, decreasing regularly in size from the older one to the younger.

Conotrochus of Seguenza and Aulocyathus of Marenzeller are two allied genera; both, however, are provided with columella which is absent in the present genus.

Goniocyathus, n. g. Genotype: G. pacificus, n. sp. (Fig. 2). Turbinoliid. Corallum simple, fragile, subturbinate, basally attached upon a fragment of septa of the parental calice (septal budding). Calice polygonal or subpolygonal, deep. Wall and septa thin; costae unequal, rather apart, and distinct only near the margin of calice; outer surface finely granulated all over. Septa undulated toward the inner margin; principal septa 14-28 in number, with three thinner and shorter ones in each interval. Columella rudimentary, papillose; pali well developed before the median of the three minor septa in each interspace of the principal ones. No epitheca.

It differs from Schizocyathus of Gravier by having pali and columella.

Deltocyathoides, n. g. Genotype: D. japonicus, n. sp. (Fig. 3). Turbinoliid. Corallum simple, bowl-shaped, keeled at the central part of the base by 2,3 or sometimes more primary septa of an older corallum which are partially enclosed. Calice circular; fossa deep. Columella rudimentary, formed of a few papillae quite indistinguishable from pali around them. Septa crowded, thin, free, margin entire, subequal in thickness but different in length, arranged bilaterally rather than radially. Costae prominent, in alternation with deep furrows which are laterally covered by spinous granules. No epitheca.

It closely resembles Deltocyathus, but its septa are all free in their inner margin and not arranged in regular cycles of the hexameral plan.

Goniocorella, n. g. Genotype: Pourtalosmilia dumosa Alc. Astroid. Corallum dendroid, branching perpendicularly by repeated 
gemmation; wall sometimes elongated to stoloniferous processes and uniting neighbouring corallites. Corallites cylindrical, narrow, almost uniformly broad throughout their length. Calice circular, deep; no columella and pali. Septa thin, distant, arranged in 3 cycles of hexameral plan, short, except for those of the first cycle which almost extend to the center of the corallite in its basal part; interseptal loculi vacant in young corallites and traversed by distant horizontal tabulae in older ones.

The genotype was assigned by Alcock to Pourtalosmilia (= Parasmilia); however, it differs from the typical forms of the genus by its cylindrical, but not funnel-shaped corallites, free from columella and distinct costae. It is more like Goniocora from the Mesozoic ; but the latter is also provided with columella.

Fig. 1.

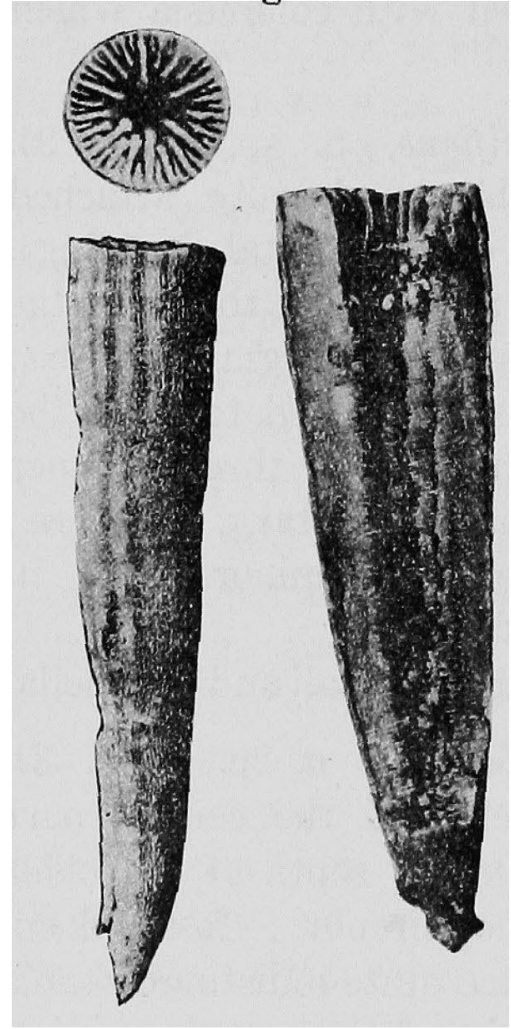

Fig. 2.

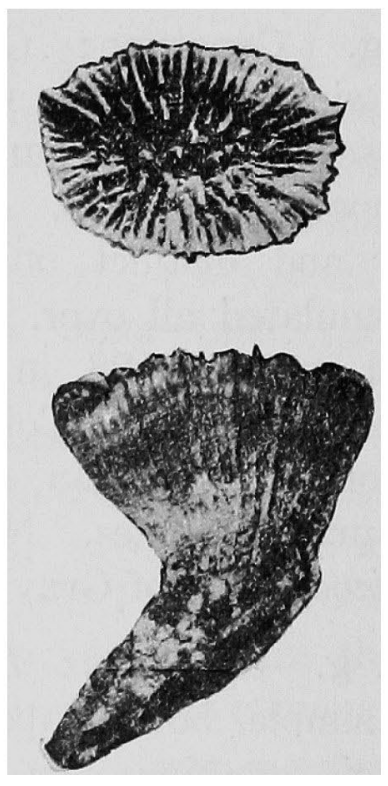

Fig. 3.

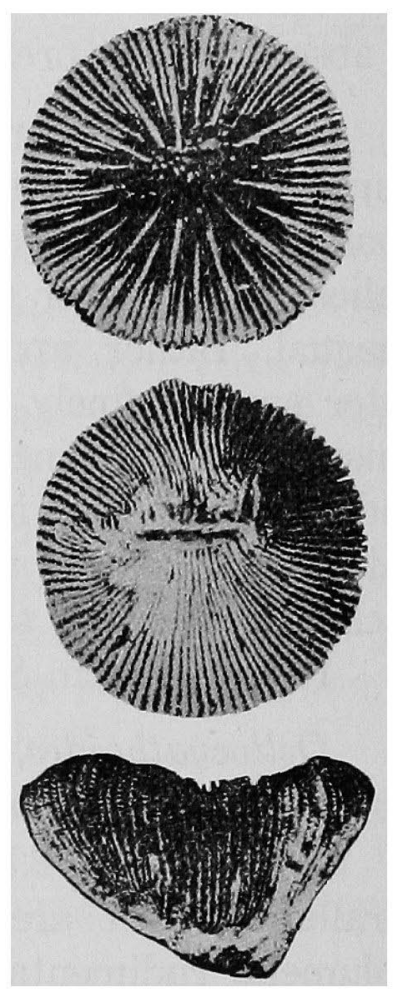

